Jurnal Adat dan Budaya, Vol 3, No 1 Tahun 2021

ISSN: E-ISSN 2615-6156, P-ISSN: 2615-6113

Jurnal Homepage: https://ejournal.undiksha.ac.id/index.php/JABI/index

\title{
PENDIDIKAN MULTIKULTURAL BERBASIS KEARIFAN LOKAL BAGI SISWA SEKOLAH DASAR
}

\author{
Asih Riyanti1 ${ }^{1}$ Neni Novitasari² \\ 1Program Studi Pendidikan Bahasa Indonesia, Universitas Borneo Tarakan \\ 2Program Studi Pendidikan Guru Sekolah Dasar, Universitas Borneo Tarakan \\ e-mail: asihriyanti17@gmail.com
}

\begin{abstract}
Abstrak
Indonesia sebagai negara yang multikultural menjadi suatu kekayaan bangsa yang harus dilestarikan. Namun, saat ini jutru pendidikan multikultural di kalangan siswa berkualitas rendah. Banyak terjadi perbedaan karena masalah budaya. Salah satu solusi yang dapat dicapai adalah menanamkan pendidikan multikultural berbasis kearifan lokal. Tujuan penulisan ini untuk memberikan gambaran mengenai pentingnya multikultural dan pembelajarannya pendidikan multikultural berbasis kearifan lokal bagi siswa Sekolah Dasar (SD). Pendekatan penelitian yang digunakan adalah kualitataif dengan melakukan kajian pustaka. Teknik analisis datanya adalah kualitatif deskriptif. Hasil dari kajian ini menunjukkan bahwa pendidikan multikultural bagi siswa sangatlah penting. Guru SD harus mendesain proses pembelajaran yang mengintegrasikan pendidikan multikultural berbasis kearifan lokal. Hal itu menjadi bagian dari kontribusi positif untuk membina sikap nasionalisme dan sikap multikultural para siswa sejak dini. Pengenalan multikultural berbasis kearifan bertujuan membentuk karakter anak negeri yang dapat menerima, memahami, dan menghargai semua orang yang berbeda ras, kepribadian, sosial, suku, adat istiadat, dan agama. Upaya pembelajaran pendidikan multikultural di SD harus dilakukan sebagai sarana pelatihan dan penyadaran untuk generasi muda, agar dapat menerima dan menghargai semua perbedaan yang multikultural.
\end{abstract}

Kata Kunci: Pendidikan Multikultural; Kearifan lokal; Siswa SD

\begin{abstract}
Indonesia, as a multikultural country, is a nation's wealth that must preserve. Currently, it is increasingly sad because of the low level of multikultural education among students. There are many differences because of the cultural feel. One solution is to instill education that can do through multikultural based on local wisdom. The purpose of this paper is to provide an overview of the importance of multikulturalism and the learning of multikultural education based on local wisdom for elementary school (SD) students. The approach used is qualitative by conducting a literature review. The data analysis technique is descriptive qualitative. The result of this study is the importance of multikultural education for students. Elementary school teachers must design learning processes that integrate multikultural education based on local wisdom. This is part of a positive contribution to fostering students' nationalism and multikultural attitudes from an early age. Wisdom-based multikultural introduction aims to shape the character of the country's children who can accept, understand, and respect other people who are different in race, personality, social, ethnicity, customs, and religion. Multikultural education learning efforts in elementary schools are training and awareness for the younger generation to accept and appreciate all multikultural differences.
\end{abstract}

Keywords: Multikultural Education; Local Wisdom; Elementary School Students

\section{PENDAHULUAN}

Indonesia terdiri dari beragam etnis yang menyebar di seluruh wilayah Nehgara Kesatuan Republik Indonesia. Masyarakat Indonesia sangat majemuk salah satunya terbukti adanya berbagai suku yang mendiami negara Indonesia ini. Berbagai suku yang ada mendiami Indonesia tersebar di beberapa pulau, termasuk suku Dayak, Tidung, Jawa, Betawi, Baduy, Minangkabau, Bugis, Toraja, Melayu, Banten, Banjar, Bali, Sasak, Dayak, Makasar, Cirebon, Arab, Cina, dan lain-lain. Ada dua perspektif untuk mengetahui kemajemukan bangsa Indonesia, yaitu secara vertikal dan hotizontal (Rismayanti \& Nusarastriya, 2020). Berdasarkan perspektif vertikal, dapat dilihat dari perbedaan budaya, mata pencaharian, ekonomi, sosial, sistem teknologi, dan pendidikan. Indonesia telah 
memiliki kemultikulturalan yang menjadi kebanggaan dan kekayaan negara. Sedangkan, kemajemukan bangsa dilihat dari horizontal dapat dilihat dari beberapa aspek, seperti perbedaan suku, bahasa daerah, agama. Suryana (2015) menambahkan bahwa yang termasuk kemajemukan secara horizontal adalah geografis, sandang, pangan, dan budaya. Perbedaan-perbedaan tersebut sudah seharusnya menjadi hal yang dapat menciptakan kehidupan yang dinamis dan rumit dengan terus menjaga dan saling menghargai. Oleh karena itu, pada siswa perlu dikembangkan sikap menghargai berbagai keberagaman di Indonesia. Adanya hal itu diharapkan dalam diri siswa tertanam sikap saling menghargai dan menghormati dengan sesama anggota masyarakat yang multikultural sehingga terdapat menunjang hidup rukun dan harmonis.

Banyaknya adat istiadat Indonesia tidak dimiliki oleh negara-negara lain. Negara Indonesia yang multikultural ini harus disyukuri karena merupakan anugerah dari Tuhan. Multikultural dikatakan sebagai ciri utama masyarakat modern (Ishmuradova \& Ishmuradova, 2019). Budaya merupakan bentuk pemahaman umum tentang cara berpikir, merasakan, dan berperilaku masyarakat atau kelompok sosial tertentu (Brown, 1963). Pendidikan multikultural adalah gerakan reformasi yang bertujuan untuk memastikan bahwa semua siswa menikmati pendidikan yang setara dan berkreasi tanpa memandang ras, jenis kelamin, budaya, bahasa, agama, kelas sosial (Kaya, 2020) (James \& Cherry, 2016). Hal itu bertujuan untuk menciptakan lingkungan pendidikan bagi semua siswa dalam kondisi yang sama yang menghargai keberagaman.

Multikuluralisme melibatkan berbagai aspek budaya seperti kelas sosial, agama, bahasa, latar belakang, usia, etinis, ras, mata pencaharian (Aydin \& Tonbuloğlu, 2014; Nakaya, 2018). Pada akhirnya, pendidikan multikultural dalam pengajaran dapat dilakukan tanpa mengkhususkan diri dalam suatu mata pelajaran. Pendidikan multikultural membutuhkan guru yang dapat menerima perbedaan individu sebagai kekayaan dan upaya untuk membuatnya kesempatan instruktif bagi semua siswa untuk membantunya meningkatkan keberhasilan akademik dan sosial. Pendidikan multikultural dapat berfungsi sebagai gerakan reformasi yang memiliki tujuan memastikan bahawa siswa menikmati pendidikan yang sama dan menciptakan pendidkan yang sama tanpa memandang budaya, bahasa, ras, kelas sosial, jenis kelamin, dan agama (Karacabey et al., 2019; Aslan, 2019; Noor, 2019). Sekolah sebagai salah satu tempat penyemai norma, nilai, dan budaya harus mengembangkan karakter para siswa agar mampu dan berkontribusi dalam mengembangkan masayarakat

Siswa dapat diberikan bahan ajar untuk mendapatkan informasi tambahan tentang keberagaman etnis di Indonesia. Ini harus menjadi keuntungan karena mempersatukan bangsa. Jika hal tersebut dilakukan, bangsa Indonesia bisa tumbuh dan berkembang secara harmonis meski ada perbedaan dalam agama, bahasa, dan budaya. Namun di Indonesia terkadang tidak demikian, karena ada konflik sosial dan budaya dapat saja apabila terjadi perbedaan pendapat dalam menyelesaikannya. Masalah tersebut dapat menimbulkan gejolak yang sedang berlangsung di berbagai daerah. Keamanan bisa tercipta jika ada yang harmonis kombinasi perbedaan multikultural. Keberagaman yang dicapai dari perpaduan yang harmonis diturunkan dari pembangunan multikultural hingga pendidikan di sekolah, khususnya SD.

Faktanya seringkali terjadi konflik antarsuku dalam kehidupan sehari-hari. Salah satu upaya pencegahan konflik adalah menciptakan pendidikan multikultural. Siswa harus dibekali sikap sadar bahwa multikultural dapat dikatakan sebagai modal integrasi, namun dapat memicu potensi terjadinya konflik apabila kurangnya kesadaran menghargai dalam diri setiap individu. Upaya pendidikan untuk menjaga bangsa adalah dengan memperkaya khasanah budaya yang dapat menjadi modal untuk membangun multikultural Indonesia (Gay \& Howard, 2000; Tilaar, 2004). Multikultural ini membutuhkan kekuatan yang mempersatukan seluruh pluralitas di negeri ini. Dengan demikian, dalam dunia pendidikan penting membelajarkan multikultural bagi siswa.

Pendidikan adalah alat dan bentuk yang disengaja dari proses budaya dan bertujuan untuk mentransfer budaya (Karacabey et al., 2019). Dunia pendidikan perlu mempertimbangkan keragaman setiap individu dalam masyarakat (ras, suku, kelas, jenis kelamin, bahasa, cacat fisik, dan lainnya). Multikultural diakui sebagai landasan persatuan untuk hidup bersama. Selain itu, dapat memperkuat kehidupan bermasyarakat yang dapat mencegah timbulnya konflik baik perseorangan maupun konflik secara berkelompok. Konflik dapat disebabkan oleh masalah yang kecil atau sederhana hingga masalah yang kompleks atau signifikan. Nilai multikultural merupakan filosofi 
yang dimaknai sebagai pandangan hidup yang ingin mempersatukan budaya selaras dengan status ekonomi, status sosial dan hak politik yang sama dalam masyarakat sipil. Hal tersebut didukung oleh pasal 27ayat 1 Undang-Undang Dasar Republik Indonesia, bahwa seluruh warga negara pada waktu yang sama dalam hukum dan pemerintahan maka wajib untuk menegakkan hukum dan pemerintahan tanpa pengecualian

Pendidikan multikultural adalah proses mengembangkan segala potensi manusia untuk menghormati dan menghargai kemajemukan serta heterogenitas sebagai bentuk konsekuensi budaya, etnis, sosial, agama, perbedaan politik, dan ekonomi. Solusi maslah sosial di masyarakat terletak pada deokrasi pularistik, dialog, dan rekonstruksiliasi (Eshabil \& Çelik, 2019). Sebagai salah satu negara multikultural yang terbesar berbagai negara, Indonesia harus dapat menjunjung pendidikan multikultural menjadi salah satu solusi untuk mencegah konflik sosial budaya yang sering terjadi. Perkembangan masyarakat multikultural Indonesia harus diupayakan secara terprogram, terintegrasi, sistematis, dan berkelanjutan. Sebab, kenyataannya multikultural di Indoensia menjadi kekuatan dan kekayaan budaya yang harus dijaga dan tetap dilestarikan. Oleh sebab itu, penting mempersiapkan tenaga pengajar profesional pendidikan multikultural, sebagai dampak dari peningkatan keragaman budaya dan ras (Eldering, 1996; Gay \& Howard, 2000; Kurniawan et al., 2019). Kompetensi multikultural adalah kemampuan memahami budaya lain dengan cukup baik untuk dapat berkomunikasi dengan orang-orang dari budaya lain. Warga negara yang baik harus memahami dengan baik tentang budaya sendiri. Biasanya ada norma budaya dalam suatu masyarakat, tetapi dapat berubah dan berkolaborasi dengan budaya lain. Semua anggota masyarakat harus kompeten untuk saling berkomunikasi agar efektif proses multikultural (Ishmuradova \& Ishmuradova, 2019). Eko et al., (2020) mengungkapkan, pendidikan multikultural adalah suatu kebutuhan, yang berawal dari kebudayaan nasional yaitu Bhinneka Tunggal Ika yang berlandaskan Pancasila, dengan tujuan umum mewujudkan masyarakat Indonesia yang egaliter dan sejahtera. Sebab itulah kearifan lokal menjadi hal menarik dan penting diketahui dan dipahami oleh para siswa.

Pendidikan multikultural berbasis kearifan lokal dalam pembelajaran di SD dapat menarik minat siswa dalam mengenal jati diri bangsa dan memiliki sikap yang mencerminkan nilai luhur Pancasila. Kartika (2016) mengatakan bahwa kearifan lokal bangsa itu dimulai dari nilai-nilai, kaidah dalam lingkungan keluarga dan selanjutnya berkembang di lingkungan masyarakat. Nilai positif terrdapat dalam kearifan lokal, yaitu mengenal masyarakat beradab dan kearifan lokal yang digunakan untuk memandu perilaku manusia dan tingkah laku alam yang bertujuan untuk menyelaraskan antara manusia yang satu dnegan yang lainnya dan antara manusia dengan alam. Tujuan pendidikan multikultural adalah mereformasi total lingkungan sekolah sehingga siswa dari kelompok budaya yang beragam akan dapat mengalami kesempatan pendidikan yang setara. Banks \& Banks (2001) mengemukakan pendidikan multikultural bertujuan untuk mengembangkan kognitif dan keterampilan siswa sehingga berfungsi dalam komunitasnya pribadi serta dalam masyarakat global.

Penelitian relevan yang pernah dilakukan adalah penelitian Eko et al., (2020), yang menemukan hasil bahwa di lingkungan sekolah-sekolah di Indonesia sudah lama kehilangan rasa jati diri, rasa memiliki, komunitas, dan kerjasama. Sekolah hanyalah tempat belajar ilmu yang cenderung transaksional, di mana guru dan kepala sekolah hanya berperan sebagai pengelola dan pemberi pengetahuan dibeli oleh pelajar. Selain itu, siswa membentuk sendiri dan forum komunikasi yang merusak dengan membentuk kelompok-kelompok (Tilaar, 2004). Siswa berkelompok-kelompok tersebut sesuka hati tanpa menghiraukan siswa lainnya. Sikap demikian mencerminkan sikap yang tidak mau menghargai orang lain dan kurangnya sikap komunikatif terhadap semua teman.

Pendidikan menjadi sarana dalam membentuk siswa agar dapat terampil berkomunikasi dengan tetap menghargai suatu perbedaan budaya. Keterampilan multibahasa dan multikultural dipandang sebagai kemampuan komunikatif yang diperlukan agar orang dapat berfungsi sepenuhnya di abad 21, dan bahasa sebagai sarana utama untuk ekspresi budaya (Kerr \& Merciai, 2016). Pengembangan pendidikan multikultural menitikberatkan pada kemampuan menghargai budaya. Hal ini perlu dibangun melalui pendidikan holistik yaitu mengajarkan siswa untuk mengembangkan konsep berpikir analitis dan berkolaborasi dengan teman untuk menyamakan 
pandangan yang terkait budaya. Dengan demikian, kajian mengenai pendidikan multikultural di sekolah sangat penting. Hal itu dikarenakan pendidikan multikultural menjadi bagian kekayaan bangsa yang perlu dijaga agar dapat menumbuhkan rasa cinta dan menghargai kearifan lokal dari wilayah lain.

\section{METODE}

Metode yang dilakukan adalah pendekatan kualitatif jenis deskriptif. Penelitian ini difokuskan pada SD yang ada di Tarakan. Waktu penelitiannya Januari sampai dengan Maret 2021. Teknik pengumpulan data yang digunakan adalah angket dan studi pustaka. Setelah data diperoleh, selanjutnya dianalisis dan dilakukan telaah pada buku-buku, artikel, serta referensi-referensi yang berkaitan dengan kajian ini. Selain itu, juga dilakukan telaah pada penelitian yang sejenis sehingga mendapat simpulan yang valid.

\section{HASIL DAN PEMBAHASAN}

Indonesia sebagai masyarakat yang multikultural memiliki berbagai kemajemukan adat istiadat, kepercayaan, ras suku, dan kebudayaan lainnya. Negara Indonesia disebut negara yang multikultural menjadi tantangan dan peluang bagi dunia pendidikan. Peluangnya adalah dapat mengenalkan budaya Indonesia sehingga negara Indonesia semakin dikenal oleh negra-negara di dunia. Adapun tantanganya jika budaya tidak dilestarikan maka akan punah dan luntur dalam jiwa orang-orang Indonesia. Oleh sebab itu, perlu dilakukan pengajaran melalui sekolah-sekolah, salah satunya di SD. Guru harus bertanggung jawab dan sadar akan adanya satu perbedaan yang melekat dalam diri siswa. Hal itu jangan sampai menjadikan perpecahan antar siswa, namun harus menajdi sebuah perbedaan yang berharga.

Perpecahan harus dihindari sedini mungkin, maka pendidikan sebagai sarana membentuk karakter siswa dengan penuh kesadaran tidak dapat meninggalkan multikultural sehingga siswa tidak meninggalkan akar budaya bangsanya. Hal ini relevan dengan pendidikan abad 21 sehingga pada akhirnya akan menghantarkan Indonesia menjadi masyarakat yang madani. Kemanjemukan budaya dapat mengurangi kesenjangan sosial dan memepersiapkan siswa dengan lebih baik untuk pasar tenaga kerja, serta mengurangi ketegangan sosial dan konflik sehingga meningkatkan solidaritas sosial. Dengan demikian, sebagai negara demokrasi maka hal itu penting untuk terus menerapkan sikap nasionalisme dan pengargaan terhadap HAM yang sesuai dengan falsafah negara.

Sebagaian besar SD di Tarakan Kalimantan Utara belum optimal dalam memberikan pembelajaran pendidikan multikultural. Guru lebih cenderung pada pencapaian kognitif siswa daripada pemahaman multikultural bagi siswa. Banyak siswa tidak dapat berbahasa daerah atau mengenal budaya lainnya. Selain orang tuanya tidak memberikan pendidikan multikultural saat di rumah, guru pun tidak memberikannya dengan optimal.

Multikultural pada abad 21 menjadi pedoman berfikir dalam mengembangkan pendidikan multikultural di SD. Ini dapat diintegrasi bahwa konten multikultural dimasukkan dalam silabus mata pelajaran, strategi pembelajaran yang tepat, dan penilaian siswa dan dinamika sosial yang timbul dari pertemuan antar budaya. Multikultural dapat diintegrasikan ke dalam berbagai mata pelajaran dengan potensi lokal daerah yang bersangkutan. Siswa dapat mulai belajar tentang pengetahuan terkait ras, kesenian, sistem teknologi, tarian daerah, bahasa daerah, identitas seksual, dan sebagainya.

Dampak pendidikan multikultural dalam bidang akademik tidak hanya kepada siswa, namun berdampak pada seluruh anggota komunitas akademis di berbagai bidang (Sela-Shayovitz \& Finkelstein, 2020). Multikultural dimulai dengan nilai, aturan dalam keluarga, kemudian berkembang di masyarakat. Pikiran manusia membutuhkan pembinaan terus menerus dan bimbingan agar dapat menjadi ajaran bagi manusia khususnya seluruh warga sekolah. Kearifan lokal dapat diintegrasikan dan diberikan terus menerus melalui pendidikan multikultural di SD secara holistik. Pendidikan holistik ialah pendidikan yang mengembangkan semua potensi dalam diri siswa secara harmoni, termasuk potensi intelektual, spiritual, sosial, emosional, fisik, estetika, dan spiritual.

Sekolah sebagai sistem yang memiliki aspek penting salah satunya dalam proses belajar. Pembelajaran berbasis multikultural yang ditanamkan di sekolah berarti sekolah telah 
mengembangkan berbagai nilai kearifan lokal dalam setiap pembelajaran. Hal ini akan menjadi pembiasaan dan peningkatan dan menerapkan nilai-nilai luhur. Kearifan lokal sebagai sebuah nilai sudah tentu tidak lepas dari sebuah kata integritas. Adanya sebuah integritas maka seorang guru akan memiliki integritas yang akan menjadi identitas sebagai ciri khas yang akan membedakan dengan pendidik lain. Lembaga pendidikan sebagai pusat pembudayaan maka guru harus dapat menggali berbagai potensi yang ada dalam budaya lokal masyarakat tersebut. Pengenalan lingkungan dan nilai kearifan lokal sangatlah beragam, maka guru harus dapat melakukan suatu perubahan pada dunia pendidikan.

Pendidikan berbasis multikultural mengajarkan siswa untuk merangkul situasi konkret yang dihadapi dalam kehidupan sehari-hari. Hasil pendidikan berbasis kearifan lokal dapat berupa keilmuan itu menggambarkan sikap dan perilaku yang mencerminkan budaya asli daerah. Bagi siswa SD, maka guru Bahasa Indonesia dapat menugaskan siswa untuk mengamati berbagai kearifan lokal. Sebagai contoh guru SD di Tarakan Provinsi Kalimantan Utara dapat mengenalkan rumah Baloy (rumah adat suku Tidung) yang ada di Tarakan yang terletak di daerah Juata Tarakan Utara. Suku Tidung sebagai suku asli yang turun temurun mendiami Pulau Tarakan. Suku tersebut memiliki kebudayaan rumah adat Baloy yang dibuat dari kayu ulin dan terdiri dari empat ruangan yang disebut sebagai ambir. Ambir kiri (alad kait) digunakan untuk tempat mengadukan masalah adat. Ambir Kanan (ulad Kemagot) sebagai ruang untuk istirahat dan ruang berdamai apabila masalah telah selesai. Ambir tengah (lamin Bantong) sebagai tempat bagi pemuka adat untuk memutuskan suatu masalah adat dan bersidang. Ambir dalam digunakan sebagai singgasana kepala adat Tidung. Selain itu, di belakang Baloy terdapat bangunan untuk menampilkan kesenin suku Tidung.

Dalam pelaksanaan pembelajaran, berbagai kearifan lokal yang dapat dipelajari siswa SD seperti kearifan dalam pepatah, nyanyian, perilaku sehari-hari, semboyan, dan upacara tradisional. Saat guru melakukan pembelajaran di kelas dapat meminta siswa berkelompok (cooperative learning) untuk melakukan pengamatan tempat ikonik di sekitar mereka dan tulis teks deskriptif tentang itu. Guru dapat meminta siswa membuat paragraf karangan mengenai potensi wisata lokal, makanan khas, baju adat dan sebagainya. Selain itu, dapat menggunakan metode mendongeng dengan kegiatan bercerita atau mendongeng dengan menggunakan foto, miniatur dalam kebudayaan misalnya rumah adatnya, alat musiknya, baju daerah dan sebagainya. Siswa SD senang dengan lagu dengan iringan musik. Pembelajaran dapat dilakukan dengan menggunakan musik daerah sebagai media belajar. Musik khas daerah dapat dibedakan oleh ras, kelas, usia, jenis kelamin, gaya hidup, maupun agama. Guru tentunya dapat memilih gaya musik khas daerah. Ini dimaksudkan dapat sekaligus mengenalkan dan mempromosikan budaya darah setempat.

Metode lainnya yang dapat dilakukan guru ialah membagikan teks deskriptif rumah adat dan meminta siswa untuk membaca teks terlebih dahulu untuk merangsang minat baca siswa. Siswa dapat mendiskusikan bersama isi teks. Guru tetap harus memperhatikan tentang tata bahasa saat membahas teks. Guru harus menjelaskan struktur umum dari teks deskriptif dan fitur bahasa. Langkah berikutnya guru meminta siswa mengidentifikasi struktur umum teks tentang rumah adat tersebut. Bercerita atau mendongeng juga dapat menjadi metode guru untuk mengukur sejauh mana pengetahuan dan memahami kearifan lokal. Kegiatan ini dapat menggunakan media pembelajaran dalam bentuk iringan musik, boneka, atau gambar-gambar yang relevan. Pada mata plajaran agama pun dapat memberikan pendidikan multikultural, misalnya saja memberikan contoh dan soal-soal agama tentang toleransi, menghormati perbedaan agama, dan sebagainya.

Tujuan dari pembelajaran multikultural ialah mengajari siswa yang percaya diri, jujur, bertanggung jawab, disiplin, dan nasionalisme. Selian itu, pembelajaran multikultural dapat mendorong kesadaran multikultural, meningkatkan kurikulum, dan menumbuhkan konsep diri (Żammit, 2021). Dalam mata pelajaran Seni Rupa, guru dapat mengajarkan cara menggambar alat musik daerahnya, rumah adatnya, menggambar seni ukiran yang ada di suku masing-masing. Dalam mata pelajaran Matematika, guru dapat mengenalkan bentuk-bentuk geometri melalui rumah adat misalnya saja bentuk atapnya, dindingnya, teras depan, dan bentuk ukiran. Pembejaran harus berpusat pada siswa, agar terjadi sikap aktif dari para siswa. Adanya pembelajaran multikultural di sekolah diharapkan mampu mengajak tokoh masyarakat misalnya saja ketua adat di daerah untuk berpartisipasi dalam mengembangkan konteks kearifan budaya daerah agar dapat dipahami dan 
dapat menciptkan keharmonisan dalam hubungan masyarakat. Efek metode pembelajaran yang berpusat pada siswa yaitu dapat meningkatkan sikap dan motivasi positif. Metode semacam itu sangat efektif dna menarik minat siswa dalam menumbuhkan kecintaannya dengan kearifan lokal di SD.

Kearifan lokal berarti sebagai gagasan lokal yang arif, bijaksana, terpatri dalam diri setiap anggota masyarakat, dihargai, dan tertanam serta diikutinya. Kearifan lokal dikenal secara adat atau kearifan lokal menjadi dasar dari identitas budaya. Desain pembelajaran kearifan lokal dalam bahan ajar berfungsi untuk mendukung pembentukan karakter. Pendidikan multikultural memanfaatkan pengalaman pembelajaran dicirikan oleh aktivitas pengalaman kreatif, hubungannya dengan keseluruhan kurikulum, dan hubungan dengan komunitas lokal. Nilai-nilai kearifan lokal sepeti kerjasama, saling menghargai di kalangan masyarakat harus tetap dijaga. Manfaat pendidikan multikultural ini dapat mencegah radikalisme di era golabalisasi. Adapun tujannya yaitu dapat menjadikan para siswa calon generasi masa depan menjadi teladan dengan penuh toleran dengan adanya perbedaan. Ada arti penting multikultural pendidikan berdasarkan pembelajaran eksperiensial (Yun \& Zhang, 2017). Perkembangan multikultural pendidikan dapat dimulai dari SD yang merupakan jenjang pendidikan formal yang paling dasar. Hal ini dikarenakan tatanan pendidikan yang diharapkan mampu menjadikan diri siswa baik warga negara dengan karakter multikultural.

Standar nasional pendidikan perlu disesuaikan dengan perkembangan daerah, nasional, dan kehidupan global di abad ke-21. Kearifan lokal dalam perkembangan kehidupan abad 21 yaitu terbentuknya masyarakat yang berkarakter budaya lokal yang positif, berpikiran terbuka, dinamis, dan teratur dalam komunikasi verba dan non verba, sehingga dapat menghasilkan keharmonisan dalam kehidupan di manapun yang berbasis Bhinneka Tunggal Ika. Nilai-nilai kearifan lokal tersebut harus diintegrasikan ke dalam kurikulum nasional agar kelas dapat berkontribusi terhadap penanaman nilai-nilai lokal kepada siswa.

Pembelajaran berbasis kearifan lokal dinilai lebih efektif daripada pembelajaran secara konvensional. Hal ini disesuaikan dengan konteks keseharian siswa sehingga pembelajaran menjadi lebih bermakna. Ini menekankan proses pembelajaran yang berpuat pada siswa. Selama kegiatan pembelajaran kontekstual, maka siswa mengkonstruksi makna berdasarkan pengalamannya sehingga pelaksanaan pembelajaran yang dilakukan dapat meningkatkan tingkat berpikir kritis dan meningkatkan hasil belajar.

\section{SIMPULAN}

Paradigma baru pendidikan pada abad 21 yaitu siap menghadapi kondisi bangsa Indonesia yang berragam sosial dan budaya. Paradigma tersebut dimaksudkan untuk mengintegrasikan kearifan lokal dalam multikultural pendidikan di sekolah. Indonesia yang majemuk ini lahir dari kekayaan kearifan lokal. Keadaran dan pentingnya sikap menghargai antarsesama dapat diajarkan dalam proses pembelajaran melalui multikultural pendidikan berbasis kearifan lokal. Guru harus mengajarkan materi pembelajaran dengan mengintegrasikan konteksnya dengan nilai kearifan lokal dalam berbagai mata pelajaran. Dengan demikian, maka dapat meningkatkan kerukunan dan hidup damai dan menyiapkan generasi muda dalam menghadapi tantangan global.

\section{DAFTAR PUSTAKA}

Aslan, S. (2019). How is Multikultural Education Perceived in Elementary Schools in Turkey? A case study. European Journal of Educational Research, 8(1), 233-247. https://doi.org/10.12973/eu-jer.8.1.233.

Aydin, H., \& Tonbuloğlu, B. (2014). Graduate Students Perceptions' on Multikultural Education: A Qualitative Case Study. Eurasian Journal of Educational Research, 57, 29-50. https://doi.org/10.14689/ejer.2014.57.3.

Banks J. A. \& C. A. McGee Banks. (2001). Multikultural Education, Issues and Perspectives. Allyn and Bacon.

Brown, I. (1963). Understanding Other Cultures. New Jersey: Prentice-Hall.

Eko, P. S., Eko, H., Munandar, M. A., \& Rachmand, M. (2020). Local Wisdom: Pillar Development of 
Jurnal Adat dan Budaya Vol. 3, No. 1, Tahun 2021, pp. 29-35

Multikultural Nations and National Education Values. Cypriot Journal of Educational Sciences, 15(6), 1587-1598. https://doi.org/10.18844/CJES.V15I6.5319.

Eldering, L. (1996). Multikulturalism and Multikultural Education in an International Perspective. $\begin{array}{llll}\text { Anthropology \& Education } \quad \text { Quarterly, 27(3), 315-330. } & \text { 2 }\end{array}$ https://doi.org/10.1525/aeq.1996.27.3.04x0352n.

Eshabil, E. P. \&, \& Çelik, S. (2019). Readiness of Turkish Education system for Multikultural education. Educational Research and Reviews, 14(8), 274-281. https://doi.org/10.5897/err2017.3171.

Gay, G., \& Howard, T. C. (2000). Multikultural Teacher Education for the 21st Century. Teacher Educator, 36(1), 1-16. https://doi.org/10.1080/08878730009555246.

Ishmuradova, I. I., \& Ishmuradova, A. M. (2019). Multikultural Education of Students as an Important Part of Education. International Journal of Higher Education, 8(7), 111-115. https://doi.org/10.5430/ijhe.v8n7p111.

James A. B \& Cherry A. (2016). Multikultural Education: Issues and Perspectives. University of Washington: Wiley.

Karacabey, M. F., Ozdere, M., \& Bozkus, K. (2019). The Attitudes of Teachers Towards Multikultural Education. European Journal of Educational Research, 8(1), 383-393. https://doi.org/10.12973/eu-jer.8.1.383.

Kartika, T. (2016). Verbal Communication Culture and Local Wisdom: The Value Civilization of Indonesia Nation. Lingua Cultura, 10(2), 89. https://doi.org/10.21512/lc.v10i2.1424.

Kaya, K. (2020). Portrayal of Ottoman Empire in Iranian High School History Textbooks. International Journal of Progressive Education, 16(2), 1-16. https://doi.org/10.29329/ijpe.2020.241.1.

Kerr, R., \& Merciai, I. (2016). EMMA: Towards Multikultural Learning. The EuroCALL Review, 24(1), 53. https://doi.org/10.4995/eurocall.2016.5696.

Kurniawan, E., Astuti, T. M. P., Utomo, C. B., \& Trimasukmana, D. J. (2019). Using Media Literacy to Prevent the Dangers of Hoaxes and Intolerance Among the Students of Universitas Negeri Semarang. International Journal of Innovation, Creativity and Change, 8(7), 1-13.

Nakaya, A. (2018). Overcoming Ethnic Conflict through Multikultural Education: the Case of West Kalimantan, Indonesia. International Journal of Multikultural Education, 20(1), 118-137. https://doi.org/10.18251/ijme.v20i1.1549.

Noor, A. F. (2019). Multikultural Education Based in the Local Wisdom of Indonesia for Elementary Schools in the 21st Century. 9(2), 94-106.

Rismayanti, \& Nusarastriya, Y. H. (2020). Upacara Adat Pemakaman Mengenang Leluhur ( Ma ' Nene ) Di Toraja, Lembang Bulalangkan Kecamatan Rinding Allo Toraja. Jurnal Adat Dan Budaya, $2(2), 118-132$.

Sela-Shayovitz, R., \& Finkelstein, I. (2020). Self-Efficacy in Teaching Multikultural Students in Academia. International Journal of Higher Education, 9(1), 159-167. https://doi.org/10.5430/ijhe.v9n1p159.

Suryana, Y. dan R. (2015). Pendidikan Multikultural"Satu Pneguatan Jati Diri Bnagsa". CV. Pustaka Setia.

Tilaar, H. A. R. (2004). Multikulturalisme, Tantangan-Tantangan Global Masa Depan dalam Transformasi Pendidikan Nasional. Grasindo.

Yun, P. H., \& Zhang, P. C. J. (2017). The Significance of the Multikultural Education Based on the Experiential Learning of a Local Community. European Journal of Social Sciences Education and Research, 10(2), 248. https://doi.org/10.26417/ejser.v10i2.p248-252.

Żammit, J. (2021). Maltese educators' perceptions of democracy, equality and justice in multikultural education. IAFOR Journal of Education, 9(1), 153-171. https://doi.org/10.22492/ije.9.1.09. 